\title{
Brak i bračne razmirice u Starom zavjetu
}

\author{
Danijel Berković \\ Biblijski institut, Zagreb \\ dberkovic@bizg.hr
}

UDK 27-242;2-555

Izvorni znanstveni članak

https://doi.org/10.32862/k1.12.2.3

\section{Sažetak ${ }^{1}$}

U uvodnom dijelu ovoga rada autor naglašava vrijednost i važnost narativnosti teksta Staroga zavjeta, prije svega da se istakne neposrednost i otvorenost $u$ starozavjetnoj narativnosti, gdje se u obliku pripovijesti bez zadrške $i$ sasvim otvoreno progovara o realnim životnim problemima. Slijedom toga otvaraju se pitanja i poimanja braka i bračne zajednice u starozavjetnom tekstu i kontekstu. Analizira se vokabular i pojmovnik. U drugom dijelu rada autor se usredotočuje na probleme bračnih i obiteljskih zajednica, bračnih razmirica onako kako to nalazimo u starozavjetnim tekstovima, uzimajući za primjer nekoliko biblijskih brakova i njihovih bračnih izazova.

Ključne riječi: Biblija, Stari zavjet, brak, bračne razmirice

\section{Narativnost starozavjetnog teksta}

Ono što tekst Staroga zavjeta krasi, u literarnom i sadržajnom smislu, a razlikuje ga od novozavjetnog teksta, jest narativnost i pripovijedna bespoštednost životnih realnosti. Osebujnost osobnih priča u tekstovima Staroga zavjeta zalazi u napete životne pripovijesti. I dok novozavjetni tekst ima poruku, starozavjetni tekst ima i poruku i priču. U središtu je Staroga zavjeta priča koja nosi poruku.

1 Članak je nastao na temelju predavanja na tribini "Od mladenačke zaljubljenosti do zrele bračne ljubavi: Biblijski pogledi na brak" održane povodom svjetskog "Tjedna braka" 10. veljače 2018. u Centru biblijskih istraživanja Biblijskog instituta u Zagrebu. 
Spasenjska poruka Novoga zavjeta tek djelomično i sporadično koristi priču i narativnost kako bi se prenijela poruka. Štoviše, u starozavjetnim tekstovima narativnost je karakteristična čak i za poetsku literaturu. ${ }^{2}$ Ako se pažljivije usredotoči i analitički čita tekst biblijskog Psaltira, ali i psalama izvan Psaltira, lako će se ustanoviti da su neke od najintenzivnijih i najnapetijih "priča ispričane upravo u Psaltiru ili drugim dijelovima starozavjetnih tekstova koji su pisani kao poezija i poetski žanr. ${ }^{3}$ Tako nam, dok čitamo poetske dijelove biblijskog teksta, samo kao svetopisamski nadahnutu poeziju, neprimjetno promakne priča koju nam je biblijski pisac namjeravao ispričati.

Stari zavjet nudi mnoge, ponekad, sasvim nemilosrdno realne životne priče. U njima se progovara bez zadrške, otvoreno i uglavnom bez eufemizama i uljepšavanja. Takav sasvim otvoreni govor, bez zadrške, zapravo je svojevrstan literarni žanr. Takav se način govora naziva parezija. ${ }^{4}$ Iako mnogi smatraju pareziju govornom figurom, bolje bi je bilo razumjeti kao svojevrstan literarni žanr. Naime, ne radi se samo o retoričkim figurama već o cjelokupnom tonu kojim odiše neki literarni uradak. Treba napomenuti da parezija nije kakav govor srodan brbljanju ili govorenju bilo čega što kome padne na pamet: „bez lučenja važna od nevažna, vrijedna od tričava" (Brnčić 2014, 181). Način je to iskazivanja kada (biblijska) priča progovara o onim nelagodnim istinama s kojima se suočava pojedinac ili cijelo društvo. Biblijski su primjeri takvoga govora Jobove žalopojke, koje prožimaju cijelu ovu biblijsku knjigu, pa ne možemo govoriti samo o retoričkim figurama nego o cijelom jednom žanru. Naime, Job vrlo otvoreno i slobodno, pomalo čak i grubo, govori o nelagodnim stvarima koje su ga zadesile, što dakako nisu bile tek nevažne i tričave stvari.

Kako ćemo vidjeti, sličan biblijski diskurs nalazimo i u biblijskim tekstovima i pripovijestima gdje se progovara o obiteljskom životu, braku i bračnoj zajednici. Biblijske priče tada postaju nemilosrdno realne, realistične i razobličene svake sentimentalnosti ili produhovljene romantike. Pokazat će se tada da Stari zavjet, progovara li o nekim nelagodnim istinama iz obiteljskog ili bračnog života, tada takav govor ima elemente parezije. Takvi tekstovi i pripovijesti ne zaobilaze in-

2 Za ovu specifičnu formu, gdje se u poetskom materijalu (pro)nalazi pripovijest, koristi se termin „narativna poezija“ (engl. narrative poetry).

3 „Poetska narativnost“ (narative poetry) neopravdano je još uvijek zanemaren literarni žanr. Doprinos Roberta Altera (The Art of Biblical Poetry) na ovu temu iznimno je vrijedan. Alter razlaže cjelokupni narativni momentum unutar poetskoga biblijskog materijala (usp. Alter 1985, 76 i dalje). O važnosti poetske narativnosti u starozavjetnom tekstu govori i ovaj autor (D. Berković) u svojoj (neobjavljenoj) doktorskoj disertaciji (str. 211, 249).

4 Sam pojam „parezija“ kao složenica dolazi od grčkoga: pan (sve) + rhsis (govor) što bi u doslovnom značenju bilo: „sve govoriti“ (slobodno govoriti). Kao retorički literarni iskaz ili govor parezija se javlja još u 5 st. pr. n. e. u antičkoj književnosti. 
timne, putene ili erotikom nabijene pripovijesti (David i Bat Šeba, Pjesma nad pjesmama), ili neke nelagodne epizode iz bračnih života (Abraham i Sara, Izak i Rebeka, Jakov i Rahela).

Svjedok neposrednosti govora o braku i bračnoj zajednici već je i sam vokabular hebrejskog teksta. Kada se govori o bračnoj zajednici, koristi se izraz: „uzeti (sebi) za ženu“ (לקח לי לאשה), gdje ovo לקח (laqah) (uzeti) naznačuje intimu i nedvosmisleno označava konzumaciju bračne zajednice. Stoga, uspostavljanje bračne zajednice (uzeti za ženu) neposredno upućuje i uključuje da leći sa ženom označuje i uspostavljanje bračne zajednice. ${ }^{5}$ Naravno, nije svaki intimni odnos sa ženom bio ujedno i oznaka bračne zajednice. Primjer tomu je pripovijest o bračnoj zajednici između Abrahama i Sare. Sara nerotkinja uputila je svoga muža Abrahama da ide i legne sa sluškinjom Hagarom, a da bi se njihovoj obitelji osiguralo potomstvo. Sara svog muža upućuje:"Hajde $k$ mojoj sluškinji, možda ću imati djece“ (בא נא אל שפחתי) (Post 16,2), što je pak kasnije prouzročilo ozbiljnu bračnu svađu. Ovdje fraza בוא אל (ući kome) zapravo znači „idi i legni sa“ (ženom). Abraham i Sara našli su se u nemaloj nevolji kada je Abraham kao gost egipatskom faraonu svoju ženu Saru predstavio kao svoju sestru, a da bi faraon tu njegovu „sestru“ uzeo za ženu, čime je zapravo i nesvjesno, počinio preljub. U toj je pripovijesti Abraham jedva izvukao živu glavu. Kada je faraon utvrdio da se ovdje ne radi o „sestri“, nego o Abrahamovoj zakonitoj ženi, faraon kaže: "Zašto si rekao: 'Ona mi je sestra', a ja je uzeh sebi za ženu (אשרה)? לאח ליח אקח אתה לי)? A sad, evo ti žene; uzmi je i hajde!' (Post 12,19). Svetopisamski tekst bez zadrške naznačuje izazove i problematiku tadašnjih bračnih odnosa. Knjiga Mudrih izreka oko bračnih problema opominje na vjerski metež i na one „koji su zastranili u spoznaji Boga" (Izr 14,22) pa „ne čuvaju više čistoće ni tijela

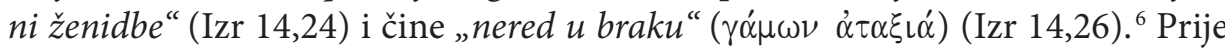
nego što krenemo analizirati neke starozavjetne bračne probleme i razmirice, sagledajmo kako se neki pojmovi i koncepti starozavjetnog svijeta u odnosu na brak povezuju jedno na drugo. To se posebno odnosi na trijadu: vjernost, monogamija i monoteizam.

5 Primjerice: Lev 20,14: „Uzme li tko sebi ženu“ (איש אשר יקח את אשה) (ŠAR) ili kako to ovdje prevodi KS: „Čovjek koji se oženi“.

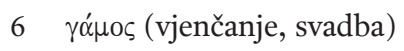




\section{BRAK U STAROM ZAVJETU}

\section{Vjernost, monogamnost, i monoteizam}

U temeljima starozavjetnog i biblijskog pogleda na bračnu zajednicu nalazi se ova neraskidivo povezana trijada između: vjernosti, monogamnosti i monoteizma. U ovakvom sklopu međuodnosa, čitatelj će prvo staviti pod znak pitanja "monogamnost" imajući u vidu poligamnu praksu starozavjetnoga svijeta. Pažljivim čitanjem biblijskog teksta uočavaju se jasne konture monogamnosti, a na što će se upozoriti i u ovome radu. Valja ipak prvo postaviti neke temeljne antropološke i religijske pretpostavke a da bi se bolje moglo govoriti o predloženoj trijadi - vjernost, monogamnost i monoteizam.

Biblijska antropologija pokazuje fundamentalnu bipolarnu odrednicu čovjekove seksualnosti i spolnosti na distinkciju muško i žensko (usp. Post 1,27). Ovako opisana spolna dualnost čovjekova bića predmnijeva i bračnu formu između dvije ljudske osobe različitoga spola, ili kako se to opisuje za prvi bračni zavjet: „čovjek će ostaviti oca i majku da prione uza svoju ženu (ודבק באשתו) i bit će njih dvoje jedno tijelo (בשר אחד)" (Post 1,24).

Ovdje pak treba napomenuti da čovjekova antropološka bipolarnost, kako je nalazimo opisanom u biblijskom tekstu, nije preslika nekih kozmološko-religijskih odnosa, onako kako ćemo to naći kroz religijsku povijest. Judeo-kršćanski religijski milje ne odražava niti oslikava neki nebeski panteon, gdje bi bog ili božanstvo imitirali muško-ženske odnose, kako to nalazimo u većini religija. U politeističkih religija bogovi žive život zemljana. Ti se bogovi žene i udaju, rađaju djecu, njihov je seksualni život prilično buran i u svemu zapravo imitira život zemljana. Dennis Prager (1993.) u svojim radovima i javnim nastupima redovito ističe činjenicu iz judaizma, kasnije i kršćanstva. Ističe kako judaizam, a kao religijski sljednik i kršćanstvo, u samom početku religijske povijesti židovstva prvo de-seksualizira Boga. ${ }^{7}$

7 „the first thing Judaism did was to desexualize God.“ "In the beginning God created the heavens and the earth" by his will, not through any sexual behavior. This was an utterly radical break with all religion, and it alone changed human history. The gods of virtually all civilizations engaged in sexual relations. In the Near East, the Babylonian god Ishtar seduced a man, Gilgamesh, the Babylonian hero. In the Egyptian religion, the god Osiris had sexual relations with his sister, the goddess Isis, and she conceived the god Horus. In Canaan, EI, the chief god, had sex with Ashera. In Hindu belief, the god Krishna was highly sexually active, having had many wives and pursuing Radha; the god Samba, son of Krishna, seduced mortal women and men. In Greek beliefs, Zeus married Hera, chased women, abducted the beautiful young male, Ganymede, and masturbated at other times; Poseidon married Amphitrite, pursued Demeter, and raped Tantalus. In Rome, the gods sexually pursued both men and women" (Prager 1993). 
U judeo-kršćanskim religijama (židovstvo, kršćanstvo, islam) muškaraci žena nisu preslika nekoga kosmičkog panteona, niti bi taj panteon bio preslika neke ljudske antropološke stvarnosti. Jedina moguća naznaka takvih preslika antropološkog i nebeskog nalazimo u tekstu o stvaranju čovjeka u Postanku, 1. poglavlju Naime, tamo se kaže da je Bog stvorio čovjeka „na svoju sliku stvori Bog čovjeka, na sliku Božju on ga stvori, muško i žensko stvori ih" (Post 1,27). No, unatoč ovom i ovakvome tekstu, u sveukupnom biblijskom tekstu i prikazima odnosa između neba i zemlje, nigdje nema naznaka da bi se ova slika odnosila na antropološko tjelesnu sličnost čovjeka i Boga-Stvoritelja (usp. von Rad 1961, 58).

\section{Vjera i vjernost}

Osnovni su pojmovi braka i bračne zajednice, temeljeni na starozavjetnim i biblijskim uzusima, vjernost i vjera. U ovome se provlači jedna usporednica odnosa, na relaciji čovjek - žena i relacija odnosa Bog - čovjek. ${ }^{8}$ Slijedeći ove biblijske uzuse, stječe se dojam da je bez oslonca, vjere, mala vjerojatnost za postojanje bračne vjernosti i vjernosti uopće. Pojam vjera, odnosno vjernost, hebrejski izvornik upućuje na semantičko polje glagola אמן (' $\mathrm{mn}$ ). U osnovnom značenju, ali i širokom semantičkom polju, אמן ima značenje = „biti čvrst, pouzdan i siguran“. Iz toga glagola i njegova semantičkog polja pojavljuju se izvedeni pojmovi, kao אמת (istina), ali i אמונה (vjernost) (usp. Višaticki 2004, 99-106). Izaija, 7. poglavlje, daje nam prvorazrednu igru riječi temeljenu upravo na glagolu אמנ u smislu: vjera, vjernost i pouzdani oslonac: „Ako se na me ne oslonite, održat' se nećete“ (אם לא תאמינו כי לא תאמנו) (7,9). Kada se govori o savezu između izraelskog Boga i njegova naroda, Izraela, kaže se da će Svetac Izraelov, Bog Izraelov, učvrstiti savez s Davidom. Savez koji će biti pouzdan, čvrst i vjeran: „Dovijeka ću mu sačuvati svoju milost; moj Savez s njim bit će vjeran (ברית נאמנת) (Ps 89,29). Zato vjera, vjernost i pouzdanost ostaju referentne točke, kako nebesko-zemaljskih, tako i ovozemaljskih odnosa.

\section{Monogamnost i poligamija}

Iz pripovijesti o stvaranju (Post 2) može se zaključiti da je brak po stvoriteljevoj nakani bio naumljen kao monogamno sjedinjenje i uzajamna vjernost jednog muškarca i jedne žene (Post 2,24). Čini se, a pokazat će se, da su monogamna

8 O tome ćemo više reći u odjeljku Monoteizam i vjernost

9 Odatle i naš današnji pojam „Amen“ kojim se nešto utvrđuje i potvrđuje u smislu: „tako neka bude“. 
obilježja braka na svojstven način očuvana čak i u razdoblju poligamije u Izraelu. Iz pripovijesti o općem potopu (Post 7) i ulasku u korablju, vidljivo je da se radi o monogamnim brakovima Noe i njegovih sinova: "Sa svojim sinovima, svojom ženom i ženama svojih sinova uđe Noa u korablju pred vodama potopa" (Post $7,7)$.

Poligamija se prvi put spominje u Postanku, 4. poglavlju, u kontekstu Kajinitske loze kada Lamek „uzme dvije žene“ (Post 4,19), Adu i Silu (Post 4,23). Čini se da je biblijski pisac (redaktor) namjerno postavio Postanak 7. poglavlje i Nou u monogamijski kontekst. Naime, Postanak 4. poglavlje i Lamek (poligamija) ilustrativan je primjer mnogih ljudskih aktivnosti, tako i braka kao utjecaja i posljedice otudenja (grijeh) od Boga, iz pripovijesti o sveukupnoj disharmoniji iz Postanka, 3. poglavlja (usp. Wenham 1987, 112). Tome ovdje zapravo svjedoče dva svijeta, jedan je svijet Noe - pravednika, a drugi je svijet Kajina - ubojice.

Što se pak monogamnosti tiče, u daljnjem biblijskom tekstu slijedi primjer Abrahama i Sare. Patrijarh Abraham čini se i po nakani je trebao imati jednu ženu, Saru (Post 12,5). Zbog jalovosti Sare, a po njezinu nagovoru, ona daje sluškinju Hagaru svome mužu Abrahamu za “ženu“: „Hajde k mojoj sluškinji, možda ću imati djece" (Post 16,2). U slučaju Abrahama ne možemo govoriti o tradiciji poligamije. Abraham je tek nakon smrti svoje žene Sare (Post 23) oženio Keturu (Post 25). U tom slučaju i s obzirom na to da je Keturu uzeo za ženu nakon smrti Sare, Ketura bi po tome njemu bila zakonita žena. Osim toga, Hagara nikada nije imala ista prava niti privilegije kao Sara, zakonita Abrahamova žena. Ovdje je zapravo riječ o tipičnom primjeru surogat majčinstva. Naime, Sara, svjesna da će Hagara s Abrahamom začeti i roditi, izjavljuje da bi ona na taj način mogla ,imati djece“. Sasvim je istovjetan slučaj u primjeru Rahele i Jakova (Post 33). Rahela, nerotkinja, upućuje svoga muža Jakova: "Evo moje sluškinje Bilhe: uđi k njoj, pa neka rodi na mojim koljenima, da tako i ja steknem djecu po njoj" (Post 30,3).

Čini se da poligamne situacije i dalje ipak nastoje sačuvati obilježja monogamnosti. I kada poligamnost postaje uobičajena praksa, postojale su jasne upute o tome koliko žena muškarac može ili treba imati. No, kao i sve drugo, i ovdje je bilo iznimaka, na što ćemo upravo ukazati. Stječe se pak dojam kako starozavjetnim tekstovima u cjelosti prevladava poligamijska kultura. Broj žena i priležnica, koje su neki biblijski muževi imali, kada bismo ih sve pobrojili, bio bi impresivan. Ipak, u tom pogledu, ne treba biti neupućen ili naivan u iščitavanju biblijskog teksta. Makar je poligamija de jure bila legitimna, de facto nije bila istinski funkcionalna, barem ne među običnim pukom biblijskih vremena. Dvije stvari treba imati na umu kada se govori o poligamijskoj kulturi, s jedne strane, i izvorno Stvoriteljevoj naumljenoj monogamiji s druge strane.

Prvo, riječ je o statusu u društvu. Svi vrli biblijski muževi, koji su uzdržavali manji ili veći harem, prema izvještajima biblijskih tekstova, dolazili su ili iz 
vladajuće kaste (David, Salomon) ili boljestojećih obitelji (Abraham, Jakov). Ipak, prosječan Izraelac toga vremena najčešće je jedva krpao kraj s krajem, a pogotovo nije bio u stanju uzdržavati neku veću bračnu poligamijski ustrojenu obitelj.

Drugo je pitanje samo funkcioniranje takvoga poligamijskog braka i obitelji. U tom slučaju, ovaj je aspekt čak važniji od statusnog i ekonomskog položaja muža u poligamijskoj bračnoj zajednici. U biblijskoj je poligamijskoj obiteljskoj zajednici i braku uvijek postojala jedna žena; femme fatale, koja je ujedno bila i mater familias. Ona je bila ta koja je držala „tri ugla u kući“. Baš kao što imamo alfa-muškarca, ova žena je u braku bila alfa-žena. O tome biblijski tekst svjedoči u cijelom nizu primjera bračnih zajednica u kojima je žena zauzimala važnu, na određeni perfidan način, čak i vodeću ulogu.

Ponovimo to još jednom, uz neke tekstualne reference. Samo neki primjeri poligamijsko-monogamnih bračnih zajednica, u kojima mater familias ima posljednju riječ: Abraham i Sara (Post 16,6), David i Bat Šeba (1 Kr 1,17; 1,28-30), Jakov i Rahela (Post 30,1-2). U ovim primjerima muž je zapravo monogamno bio vezan uz svoju ženu, obavezan prema njoj koja je imala ulogu mater familias, pa je na taj način pripadao samo jednoj svojoj ženi. ${ }^{10}$

$\mathrm{U}$ povijesnom naslijeđu bračne monogamnosti, od starozavjetnih vremena do naših dana, zanimljivo je uočiti kako je pojam braka jezično i etimološki određen u hebrejskom izvorniku. Za bolje razumijevanje židovskog braka i monogamnosti presudna su dva pojma i korijena riječi.

Jedan od tih pojmova je nisuim (נישוים) (svadba), a drugi je qidušin (קידושין) (zaruke). Prvi od ovih dvaju pojmova (nisuim) dolazi od glagolskog korjena nasa (נשה), ,ponijeti“, „podići“ ili „nositi teret“. Drugi pojam (qidušin) dolazi od riječi qadoš (קדש) „svet“, „cjelovit“, „odvojen“. Irun Cohen $(2017,46)$ ovako zaključuje,

Kadoš znači biti označen, različit, posvećen, odijeljen, naročit. Kadoš je poseban. Vjenčanje je kidušin, oznaka isključive veze određenog muškarca i određene žene. U hebrejskom činimo nešto svetim uspostavljajući s time odnos, pozitivno to razlikujući od svega ostaloga, individualizirajući ga posebnim pravima i obavezama.

Pojam qadoš (svet) u biblijskoj i židovskoj religijskoj i jezičnoj povijesti uvijek je označavao posebnost uzajamnih odnosa. Kako između pojedinaca u ljudskoj zajednici, tako i između čovjeka pojedinca i Boga. U tom je pogledu bračna zajednica qadoš ili qidušin između jednog muškarca i jedne žene. Izvan ovakve

10 Upravo je bračna zajednica Abrahama i Sare ilustrativan primjer gdje Sara nedvojbeno zauzima u tom braku položaj mater familias (usp. Post 16,5-6), što će se kasnije ponavljati kroz cijeli starozavjetni tekst. 
veze, drugo i drugačije intimno povezivanje muškarca i žene ipak je samo stvar priležništva. ${ }^{11}$

\section{Monoteizam, vjernost i brak}

Na koji se način povezuju ili nadovezuju pojmovi - monoteizam, vjernost i brak? Gdje je poveznica monoteizma i vjernosti u odnosu na poimanje braka u Starom zavjetu? Pretpostavimo da se ovi pojmovi - monoteizam i vjernost - predstave kao dva smjera koja se sjeku u sjecištu vertikalne i horizontalne linije. Vertikalna linija predstavlja odnos neba i zemlje, Boga i čovjeka. Horizontala pak predstavlja zemaljski odnos na ravni i po pravcu odnosa čovjek-čovjek. U sjecištu ovih dviju pravaca nalaze se pojmovi monoteizam i vjernost. Po vertikali se ispružaju odnosi Boga i čovjeka, a po horizontali uzajamno prema bližnjem. Za oba je ova odnosa nasušna potreba vjernost, prema Bogu i prema čovjeku.

Vertikalna uzlazna linija prikazuje čovjekovu vjernost prema Bogu, silazna pak vjernost Boga u odnosu na čovjeka, posebno prema svojim izabranicima. Da bi bila potpuna i djelotvorna, ova vertikala treba biti dvosmjerna, silazno-uzlazna. Bog je vjeran čovjeku, a čovjek Bogu. Ovu silaznu vertikalu, vjernost Boga prema čovjeku, novozavjetna teologija iskazuje Božjim spasenjskim ispružanjem. U starozavjetnom kontekstu ta silazna vertikala predstavlja vjernost Izraelova Boga prema njegovu odabranom narodu. U horizontali ovo je također dvosmjerna i uzajamna komunikacija čovjeka prema bližnjemu. Dok je u bračnoj zajednici to vjernost jednoga čovjeka prema jednoj ženi. Ovo križanje sjecišta odnosa, vertikale i horizontale, doživjelo je svoj rasap i raspad u sveopćoj disharmoniji, prema izvještaju u Postanku, 3. poglavlju. Kako u odnosu čovjeka s obzirom na Stvoritelja (vertikala), tako i čovjeka prema čovjeku (horizontala) (usp. Post 3,14-19). ${ }^{12}$ Treba pobliže pogledati kako ova dva smjera i njihovo sjecište u monoteizmu i vjernosti upućuju na poimanje braka. Za bolje razumijevanje ove prispodobe treba imati na umu dvije stvari.

Prvo, u vertikali (odnos Bog - čovjek) Bog je nepodijeljeno vjeran i pouzdan prema svojoj jedinoj „izabranici“ (narodu koji je izabrao), što nas pak upućuje na monogamnu bračnu zajednicu. Drugo, u oba ova smjera, vertikalnom i horizontalnom, čovjek često iskazuje svoju nevjernost, kako prema Bogu (vertikala),

11 Treba napomenuti da je u biblijskoj povijesnoj praksi muškarac ipak bio privilegiran. Bludnicama se sudilo kamenovanjem, bludnik, muškarac, rijetko je bio podvrgnut istom takvom tretmanu.

12 Prva bračna zajednica (Adam i Eva) doživljava svoju prvu razmiricu, koju karakteriziraju i druge bračne zajednice Staroga zavjeta, a koje su uzrokovane međusobnim okrivljavanjima bračnih partnera. 
tako i prema bližnjemu (horizontala). Božja „izabranica“ svoju nevjernost pokazuje u mnogobožačkoj idolatrijskoj praksi Izraelaca, u zemaljskoj stvarnosti, to je nevjernost u bračnoj zajednici, kao i koruptivnoj praksi prema bližnjemu (usp. Iz 1,16-17).

\section{Bogje vjeran}

Vjernost nije djeljiva na više dijelova. Iskažemo li to suvremenim vlasničkim odnosima, geodetsko-gruntovnim rječnikom, vjernost je jedan-kroz-jedan (1/1), ona nije djeljiva na više vlasnika. Stoga, u pripravi Izraelaca za ulazak u zemlju obećanja izdana su dva upozorenja. Jedno se odnosi na to da se ne ulazi u saveze, političko-strateške, s narodima koje će Izraelci ondje zateći (Pnz 7,2b), ali niti ulaziti s njima u bračne zajednice $(7,3)$. Ovaj odjeljak (Pnz 7,2-9) završava na način da sasvim nalikuje bračnom savezu. U tome se Svevišnji iskazuje i prepoznaje kao onaj koji je „tvoj“ i “vjeran“: "Zato znaj da je Jahve, Bog tvoj, pravi Bog, Bog vjeran, koji drži svoj Savez i milost svoju iskazuje do tisuću koljena onima koji ga ljube i drže njegove zapovijedi" (Pnz 7,9).

Nakon iskaza svoje nepodijeljene vjernosti u reciprocitetnom odnosu, slijedi poziv nalik zaručničkom: „Budi posve vjeran/vjerna Jahvi, Bogu svome“ (Pnz $18,13)$.

\section{Bogje suprug}

Po već spomenutom vertikalnom obrascu odnosa neba i zemlje, taj se odnos u biblijskim tekstovima redovito prispodobljuje i temelji na bračnoj i zaručničkoj vezi. Bog je zaručnik ili već suprug Izraela, svoje zemaljske nevjeste. Takve se analogije posebno ističu i tematski razrađuju u proročkoj literaturi. U proroka Hošee (Hoš 1) nebeski se zaručnik osjeća prevarenim, svoju zemaljsku nevjestu uspoređuje s bludnicom pa proroka upućuje: „Idi, oženi se bludnicom" (Hoš 1,2). Ipak, unatoč ovome teškom razočaranju, nebeski zaručnik ne odustaje pa se zarekao: „Zaručit ću te sebi dovijeka; zaručit ću te u pravdi i u pravu, u nježnosti i u ljubavi“" (Hoš 2,21). Za razliku od tog i takvog razočaravajućeg iskustva kod Hošee, prorok Izaija prikazuje Boga kao supruga koji tješi osramoćenu i ostavljenu ženu, udovicu:

Ne boj se, nećeš se postidjeti; ne srami se, nećeš se crvenjeti. Zaboravit ćeš sramotu svoje mladosti i više se nećeš spominjati rugla svoga udovištva. Jer suprug ti je tvoj Stvoritelj, ime mu je Jahve nad Vojskama; tvoj je Otkupitelj Svetac Izraelov. (Iz 54,4-5)

Prispodoba ostavljene žene, njezina udovištva i novoga braka, u kojem Svevišnji kao suprug uzima ostavljenu ženu, zaslužuje dodatnu analizu. U ovoj bračnoj prispodobi suprugu pripada patrijarhalni autoritet. No $\mathrm{u}$ istome tekstu, $\mathrm{u}$ istoj osobi supruga, pojavljuje se i lik Otkupitelja. Intrigantno u ovoj metafori jest to 
što Otkupitelj nema autoritet kao što ga ima Suprug, ali ima obavezu brigu i zbrinjavanja ostavljene. Nebeskom mužu nevjesta je Izrael, kao zemaljska izabranica, u novozavjetnom tekstu Krist je zaručnik koji ima zemaljsku nevjestu Crkvu (Iv 3,29; 2 Kor 11,2; Otk 18,23; Otk 21,9). U oba slučaja brak i bračna zajednica preslika su odnosa po obje linije, onoj vertikalnoj (nebo - zemlja) i onoj horizontalnoj (zemlja - zemlja). U oba je slučaja monogamna vjernost zajednički nazivnik.

\section{Bog je otkupitelj}

Monoteistički se kontekst Božje vjernosti (Suprug i Otkupitelj) posebno ističe u prvoj zapovijedi Dekaloga. Suprug i Otkupitelj iz Izaije 54,5 u prvoj zapovijedi Dekaloga ponovno se identificira kao Otkupitelj. Ovdje je to onaj koji je Izrael „izveo iz zemlje egipatske, iz kuće ropstva“(Pnz 5,6). U takvom supružničko-otkupiteljskom tonu ova zapovijed Dekaloga nastavlja u monoteističkom tonu, čemu je zapravo izravno zajednički nazivnik usporednica s bračnom vezom, stoga: „nemoj imati drugih bogova uz mene" $(5,7)$. Ovdje bi se ovo "bogova" lako moglo zamijeniti rječju "muževa“. Vokabular braka znakovito se nastavlja. Izraelov Bog je „Bog ljubomoran“ (אל קנא) (Pnz 5,9). Unatoč tomu i toj ljubomori, ljubomora ovog Supruga i Otkupitelja ne iskaljuje se patološkom agresijom niti osvetoljubivošću. Štoviše, očituje se kao ljubav prema vlastitu narodu i prema zemlji u kojoj obitava taj narod. Naime: „Jahve, ljubomoran na zemlju svoju, smilova se svom narodu“ (ויקנא יהוה לארצו).

Sve navodi na zaključak da se i u Starome zavjetu brak zasniva na monogamnoj zajednici, temeljenoj na nepodijeljenoj i čvrstoj vjernosti supruga i supružnice. Upravo onako kako se to iskazuje u monoteističkom obrascu vjernosti jednoga Boga prema svom narodu, svojoj izabranici.

\section{Brak u kontekstu biblijskog teksta}

\section{Što je Bog združio?}

U biblijskom starozavjetnom i novozavjetnom tekstu i kontekstu brak je sakramentalne naravi pa se kao zajednica smatra „božanskom zajednicom“ muškarca i žene (Post 2,24; Mt 19,6), što je „vidljivi znak nevidljive božanske milosti“. Dakle, utvrđivanje bračne zajednice pripisuje ljudskoj suglasnosti supružnika, ali pod božanskim "pečatom“. Biblijski tekst to ovako definira: „Što je Bog združio (svezao), čovjek ne smije rastavljati“ (Mt 19,6). Problematika braka ili, nazovimo

13 Usp. Jak 4,5 "Mislite li da uzalud Pismo veli: Ljubomorno čezne za duhom što ga je nastanio u nama?" 
je, knjiga braka iz judeo-kršćanskog ugla gledanja čini se da je zatvorena knjiga. ${ }^{14}$ Slijedimo li pažljivo biblijski tekst, čini se nedvojbenim da je brak zajednica muškarca i žene.

S druge strane, postoje i neka otvorena pitanja pa se čini da je ta knjiga još "odškrinuta“. Ovo se posebno odnosi na sklapanje i razvrgnuće braka.

Osim što su doktrinarno određeni, sastavljanje i rastavljanje bračnih zajednica također su i kulturološki fenomen. Ako Svevišnji osniva bračnu zajednicu, u kulturološkim i vjerskim previranjima očito je da Bog nije baš uvijek bio taj koji je "združio" baš svaki brak. Primjerice, iz biblijskog teksta nije baš lako zamisliti da bi brak između kralja Davida i Bat Šebe mogao biti Bogom združena bračna zajednica, imajući u vidu povijest nastanka ove bračne zajednice. Što zatim reći o svim onim ugovorenim brakovima koji su se sklapali, možda i mimo toga da ih je baš združio Bog? Kasnije u povijesti, Crkva preuzima božanske ingerencije u zapečaćivanju ili razvrgavanju brakova. Gdje se, dakle, nalaze ingerencije odgovornosti posljedičnih rezultata, sklapanja ili „rasklapanja“ bračnih zajednica?

\section{Vokabular braka}

Ono što starozavjetne bračne priče čini dodatno intrigantnim jest i vokabular braka u hebrejskom izvorniku. U tom tekstu zapravo uopće nećemo pronaći imenični ili pridjevski oblik riječi „brak“ i "bračni“. ${ }^{15}$ Najbliže riječi „ „brak“ pronaći ćemo u Postanku, 34. poglavlju, u pripovijest o incidentu koji se dogodio Jakovljevoj kćeri Dini. ${ }^{16}$ Šekem, Hivijac, silovao je Dinu, što je izazvalo konflikt i potencijalno ozbiljan sukob između Izraelaca i Hivijaca. Hamor, Šekemov otac, kako bi smirio strasti, Jakovu predlaže:

Hamor im reče: "Moj se sin Šekem svom dušom zaljubio u vašu kćer. Dajte mu je za ženu! Oprijateljite se s nama (התחתנו): dajte nam svoje kćeri, a naše kćeri uzimajte sebi!“" (Post 34,8-9)

Ovo התחתנו (hithatenu), što se prevodi kao: „oprijateljite se s nama“(KS), u većini engleskih rečenica to se prevodi kao: "make marriages with us" (NRS, RSV). ${ }^{16}$ Ova konstrukcija התחתנו, dolazi od imenice (ženin otac, svekar), na ovaj se način u ovom obliku (hitpael imperativ) javlja samo u ovome tekstu. Osim for-

14 Judaistički pogledi na brak (SZ), kršćanska vizura (NZ), kao i islam (Kuran), uglavnom su jedinstveni oko naravi bračne zajednice, kao bogomdane i nerazvrgljive.

15 Izuzev Pj 3,11 u imenici: חתנה (חתנה) (ת) deverbal od glagola). Ova je imenica „biti ili postati kćerin muž“ (zet), ili „biti ženin otac“. O denominativima i deverbalima, usp. Jouon 1993, 34c.

16 Dina je Jakovljeva kći koju mu je rodila Lea (Post 34,1 ). Iako je Jakov bio sasvim zaljubljen u Labanovu mlađu kćer Rahelu, Laban je Jakovu podmetnuo Leu za ženu (Post 29,21-26) umjesto Rahele. ${ }^{16} \mathrm{NAB}$ (New American Bible) ovdje prevodi sa: 'Intermarry with us'. 
malne bračne zajednice, također se i erotski dio pripisuje braku, čemu svjedoči knjiga Pjesme nad pjesmama. ${ }^{17} \mathrm{U}$ toj biblijskoj knjizi, koja zbog svoga erotskog naboja postaje vrlo specifična biblijska knjiga, nalazimo termin svadba iz istog korijena חתן. Dan svadbe je (יום חתנה) (yom hatanah) (Pj 3,11).

"Izađite, kćeri sionske, i vidite kralja Salomona pod dijademom kojim ga mati ovjenčala na dan svadbe (יום חתנה) njegove, na dan radosti njegova srca" $(3,11) .{ }^{18}$ Uz ovaj imenični korijen חתן, koji upućuje na bračnu zajednicu, jedini sljedeći oblik, koji upućuje na bračnu zajednicu, dolazi od glagolsko-imeničnog oblika בעל (ba’al) (gospodovati nad, gospodin). Ba’al je onaj koji je „gazda“ nad svojim domom ili gazdinstvom (usp. Post 31,35), što je vokabular podložnosti. Jakov će u strahu za svoj život svoga brata Ezava nazvati „moj gospodar“ (Post 32,5; Post $33,14) .{ }^{19} \mathrm{~Pa}$ se u Izaiji 54,1 žena u bračnoj zajednici jednostavno naziva kao „udata“"(בעולה) (beulah). Dakle, ona koja je pod "gazdinstvom" svoga supruga. ${ }^{20}$

\section{BRAČNE RAZMIRICE}

\section{Bračne razmirice}

Vezano uz životnu realnost bračnih razmirica, njihovih uzroka i posljedica često nas podsjeća ono već proverbijalno biblijsko geslo: „pod suncem ništa nova“ kao i ono „što je bilo opet će biti“. Mnoge nam biblijske pripovijesti o životu obitelji i bračnih zajednica pomalo nemilosrdno oživljavaju i našu suvremenu stvarnost. Obiteljsko-bračne razmirice iz drevnih biblijskih vremena gotovo su identične onima danas. Već su tada bili vrlo aktualni i dobro poznati obrasci bračnih ponašanja u razmiricama. Ovi se obrasci mogu sažeti prema sljedećim uzorcima ponašanja bračnih partnera:

- prebacivanje krivnje na drugog supružnika („nisam ja nego...")

- izlijevi ljubomore („gdje si bio/la?")

17 Istina, erotika i erotski nagon u biblijskom tekstu ne pripisuje se samo braku i bračnoj zajednici.

18 Ovo je ujedno i jedini put kad se pojavljuje imenica חתנה (svadba). O etimologiji ove jedinstvene uporabe termina חתנה vidjeti u Keil i Delitzsch 1983, 6:69.

19 Kao sinonimijski oblik za בעל (gazda) javlja i אדון (gospodin).

20 Vrlo je intrigantna etimologija riječi „brak“ u ivritu (moderni hebrejski današnje države Izraela), gdje termin "brak“, "bračni“, „oženjen“ itd. etimološki proizlazi iz glagola נשח (nasa) (podići teret, nositi breme). Stoga, imamo: „biti oženjen“ (נשוא) ili „נשואה), „,oženjeniti udata (נשואים). 
- djeca kao izvor bračnih problema („nikada ništa od njega/nje“)

- neplodnost muža ili žene („ostali smo sami“)

- mačo-muškarac i dobra žena („mudra žena i glup muž“).

Sve ovo i više, pronaći ćemo, koliko u biblijskim tekstovima, toliko i u bračnim pričama današnjice. Odabrali smo nekoliko karakterističnih biblijskih priča o bračnim razmiricama koje su u biblijskoj pripovijesti i povijesti ostavile duboki trag. Mnogi od ovih tekstova zapravo su etiološke naravi, odnosno te su pripovijesti zapravo ispričane kako bi opisale buduće posljedice.

Odabrali smo nekoliko biblijskih bračnih parova uz svojevrsna gesla sporova po kojima su se odvijale razmirice u ovim bračnim zajednicama: Adam i Eva („nisam ja“); Sara i Abraham („ostali smo sami“); Izak i Rebeka („velika djeca, velika briga“); Rahela i Jakov („dosta mi je svega“); Nabal i Abigaila („ljepotica i budala“).

\section{Adam i Eva: „Nisam ja, ona/on je“}

Jedan od najčešćih razloga bračnih razmirica uzajamno je prebacivanje krivnje među supružnicima. Uglavnom se svodi na zajednički nazivnik prema obrascu odgovornosti: „nisam ja, ona/on je...“ U biblijskom tekstu prva zabilježena bračna svađa jest ona između Adama i Eve. Njihova je kratka bračna idila kulminirala vrlo neobičnim uzajamnim prebacivanjima odgovornosti i još neobičnijom presudom nebeskog arbitra u toj razmirici.

U središtu ove razmirice javlja se važan biblijski motiv koji je u ovom slučaju prouzročio bračnu razmiricu. To je onaj vječni motiv požude ili žudnje, u čijem se središtu uvijek nalazi ono što je: „oku zamamljivo“ (Post 3,6). U Postanku, 3. poglavlju, kao i u Postanku, 6. poglavlju, ono što je „oku zamamljivo“ želja je toga se dočepati. Kao i u svim pripovijestima o žudnji, slijedi nam glagol לקח (laqah) (uzeti, prisvojiti), koji se pak često pojavljuje u kontekstu putene seksualne želje ili čina. Nakon želje ili žudnje što vrije u čovjekovu umu, slijedi akcija ispružene ruke, dohvaćanja i uzimanja. Ovome je indikativan tekst Postanka 6,2 iz pripovijesti o tzv. sinovima Božjim, tkogod da oni bili. Tekst pokazuje i objedinjuje dvije nerazdvojne komponente žudnje.

Prvo, činu prethodi: žudnja oka, kolokvijalnim rječnikom to je kao da su " $b a$ cili pogled". Nakon toga slijedi čin, a to je ispružena ruka i uzimanje objekta žudnje, ponovno običnim rječnikom to je "samoposluživanje". Kada se prvi bračni par trebao suočiti s rezultatima i posljedicama ovoga čina, protivnoga Božjem naputku (Post 2,16-17), slijede razmirice i uzajamno prebacivanje krivnje između prvih supružnika i Boga Stvoritelja.

Žena (Eva) se opravdava i prebacuje krivnju na zvjerku koja bijaše lukavija od sve zvjeradi: „Zmija me zavede; zato sam jela“ (Post 3,13). U ovom prebacivanju krivnje u maniri Pilatova pranja nevinih ruku, muž (Adam) smogne hrabrosti da krivnju prebaci na samog Stvoritelja, a svoju (ne)odgovornost pravda riječima: 
"Žena koju si stavio uza me - ona mi je dala sa stabla, pa sam jeo"(Post 3,12).

Rezultat ove prve bračne razmirice opisan je u riječima nebeskog arbitra: „Neprijateljstvo ja zamećem između tebe i žene, između roda tvojega i roda njezina" (Post 3,15). Ova etiološka priča ukazuje na trajne posljedice i sveukupnu disharmoniju koja je zavladala na temelju jedne bračne svađe, ali i neprihvaćanja vlastite odgovornosti. Postavlja se pitanje, za jedno drugo razmatranje, nije li ono sudbonosno „stablo spoznaje“ trebalo ograditi žilet-žicom? ${ }^{21}$

\section{Sara i Abraham: "Prošlo je vrijeme smijeha"}

Neke idilične bračne priče počinju skladnim i opuštenim odnosima, koji se lako zakomplicira kakvim incidentnim događajem ili nepromišljenim odlukama. Jedan pomalo ciničan biblijski pisac kaže da sve ima svoje vrijeme: "Vrijeme smijeha; vrijeme tugovanja i vrijeme plesanja" (Prop 3,4). Abraham i Sara možda nisu toliko plesali, ali su imali svojih velikih briga vezanih uz potomstvo s obzirom na to da je Sara bila (a) nerotkinja i još (b) u poznim godinama (Post 16,2). Ipak, stiže nebeska intervencija i obećanje o tome da će Sara zatrudnjeti, što nju navodi na ciničan podsmijeh (Post 18,12).

Slijedom pak izvještaja iz Postanka, 16. poglavlja, Sara nakon svih frustracija svoje jalovosti donosi odluku, čime preuzima i odgovornost. Slijedimo li pažljivo biblijske tekstove iz njihovih bračnih priča, Sara je očito bila mater familias (vidi gore: Monogamnost i poligamija). Ovom odlukom ona svoga muža, Abrahama, upućuje sluškinji Hagari: „Hajde k mojoj sluškinji, možda ću imati djece“ (Post 16,2); nedvojbeno, i bez kakvog pogovora, opaske ili sugestije, Abraham to posluša (Post 16,2c). Sama činjenica da je Hagara začela (16,4b) postaje uzrokom ljubomornih bračnih razmirica između Sare i Abrahama. Sara se okomljuje na muža riječima: „Nepravda što se meni nanosi tvoja je krivnja“ (16,5), ali po kojoj logici stvari? Bračna se razmirica dalje zahuktava kada Sara počinje zazivati ime Božje: „Jahve sudio i meni i tebi“ (Post 16,5c). Sara u datoj situaciji, gdje na nju Hagara gleda s prijezirom, zahtjeva zaštitu svoga muža (usp. von Rad 1961, 193). Abraham, vidjevši dokle je došao taj obiteljski sukob, distancira se od Hagare, riječima upućenim svojoj ženi Sari: „Tvoja je sluškinja u tvojoj ruci“(Post 16,6), tj. čini s njom što te volja. Iako, valja primijetiti da Abrahamu nimalo nije bilo drago što je njegova žena potjerala Hagaru i njihova (?) sina Jišmaela (usp. Post 21,11). Ovaj bračni i obiteljski incident još jednom potvrđuje kako je starozavjetna poligamija relativan pojam. Ova bračna zajednica i Sarina uloga zorno pokazuje da su brak i bračna zajednica u osnovi monogamne naravi.

21 Usporedba s migrantskom krizom 2017. godine u Europi, kad su Mađarska i Slovenija na svojim južnim granicama postavile žilet-žicu radi zaustavljanja ulaska emigranata u njihovu zemlju (op. ur.). 


\section{Izak i Rebeka: "Velika djeca, velika briga"}

Jedan od izvora bračnih i obiteljskih napetosti često su djeca, a što slijedi onu proverbijalnu narodnu: "mala djeca, mala briga; velika djeca, velika briga". U izazovima s "velikom djecom" obiteljske biblijske priče očito su intrigantne i poučne. Ukazuju na situacije kada se "velikoj djeci" tolerira sve i svašta pa su, ne samo svojim roditeljima i obitelji, postajali izvorom mnogih problema. Mnogi biblijski uglednici (Eli, Samuel, David) svoje sinove nisu mudro odgajali (usp. 1 Sam 3,13; $1 \mathrm{Kr}$ 16). Neki su od njih svoje sinove toliko razmazili, što im se kasnije obijalo o glavu, da su postali i prijetnja nacionalnoj sigurnosti. Za Adoniju, Davidova sina, koji je sam sebe namjerio postaviti za kralja, biblijski tekst ovako govori:

Adonija, sin Hagitin, uzoholi se i pomisli: "Ja ću biti kralj!" Zato nabavi sebi kola i konjanika i pedeset ljudi koji su išli pred njim. Njegov ga otac za svoga života nikad nije ukorio niti ga kad upitao: “Zašto tako činiš?" Bio je, osim toga, stasit i lijep, a mati ga rodila poslije Abšaloma. (1 Kr 1,5-6)

Kao rezultat takvog odgoja, Adonija postaje i uzrokom obiteljske razmirice. I dok mu je otac na samrti (1 Kr 1,4-5), Adonija sebe narcisoidno priprema za budućega kralja. ${ }^{22}$

Djeca se ne rađaju in vacuuo, ona dolaze na svijet nedužna i čista, ulazeći u već zatečeni kontekst svojega roditeljskog i obiteljskog doma. Čak kada bi i otac i majka bili idealni roditelji, obiteljski je krug širi od roditeljskog doma. Ilustrativan je primjer Izakova ženidba u obitelj Rebeke i njezina brata Labana, što se zapravo pokazalo kao disfunkcionalna obitelj. To će se kasnije posebno pokazati u životu Rebekina sina Jakova, kojega će Laban, majčin brat, nemilice iskorištavati i varati.

U primjeru bračnoga para Izaka i Rebeke, maksima: "velika djeca, velika bri$g a$ “ ispunjava se u svakom pogledu. Neka ponašanja njihova sina Ezava postaju izvor ogorčenja njegovoj majci i ocu te unose nemir u obitelj. Ako načas izuzmemo etiološko-teološke aspekte ove biblijske priče, pa se usredotočimo samo na obiteljsko ozračje, evidentne su bračne i obiteljske napetosti. U prenatalnoj fazi i teškoćama tijekom trudnoće, Rebeka sluti buduće probleme, pa uzvikuje: „Ako je tako, zašto ću živjeti“ (Post 25,22). Sluteći već tada da će odnosi njezinih sinova blizanaca u životu biti teški, problematični i konfliktni, s obzirom na to da su se djeca "već u njezinoj utrobi tako sudarala“ $(25,22)$. Tako će se ubuduće odnosi ove braće blizanaca znatno odraziti i na odnose unutar bračne zajednice njihovih roditelja.

Von $\operatorname{Rad}(1961,265)$ ispravno primjećuje kako je priča o ovoj obitelji sasvim realistična, bez ikakve idealizacije, bilo Jakova ili Ezava. Iako pripovijest jest etiološke naravi i ukazuje na rascjep u nacionalnoj povijest, pitanje je ko- 
liko su roditelji toga bili svjesni. U ovom aspektu različitosti između Jakova i Ezava, von $\operatorname{Rad}(1961,265)$ zanimljivo komentira neke pojedinosti u biblijskom opisu ove dvojice braće (Post 25,24-28). ${ }^{23}$ Činjenica da su životni putovi njihovih sinova, Jakova i Ezava, krenuli sasvim drugačijim putovima i smjerovima, unijelo je u brak Izaka i Rebeke dodatne napetosti. Nakon teškog konflikta između njihovih sinova, Ezav se obvezuje na krvnu osvetu svome bratu Jakovu (Post 27,41). Sve to opterećuje bračne odnose njihovih roditelja. Osvetoljubivi Ezav, dodatno iz inata svojim roditeljima u situaciji u kojoj se našao prevarenim, ženi se Hetitkinjama, „Kad je Ezavu bilo četrdeset godina, uzme za ženu Juditu, kćer Hetita Beerija, i Basematu, kćer Hetita Elona" (Post 26,34). ${ }^{24}$ Ovo je, kako svjedoči biblijski tekst, postao izvor ogorčenja između Izaka i Rebeke (usp. Post 26,35).

\section{Rahela i Jakov: "Dosta mi je svega"}

Nakon uzajamnih prebacivanja krivnje (Adam i Eva), ljubomornih ispada (Sara i Abraham) i disfunkcionalne obitelji (Izak i Rebeka), ponovno se bračne razmirice vraćaju u pripovijesti o djeci u bračnoj zajednici Jakova i Rahele, onog istog Jakova koji je sazrijevao u disfunkcionalnoj obitelji oca i majke (Izaka i Rebeke) i majčina brata Labana. Bračna priča Rahele i Jakova još je jedna od klasičnih priča iz Knjige Postanka, iznova s dodatnim nabojem oko nasušne potrebe da se priskrbi nasljednik. Dakako, da bude sin "muškić“ budući da se žensko dijete ne računa kao nasljednik. ${ }^{25} \mathrm{U}$ takvoj konstelaciji i frustraciji zbog nemogućnosti da zatrudni, Rahela prema svome mužu Jakovu reagira eruptivno: „Daj mi djecu! Inače ću svisnuti! (מתה אנכי)" (Post 30,1). U najdoslovnijem smislu ovo bi se prevodilo kao: „Daj mi djecu! Inače sam mrtva“.

Reakcija Jakova, sukladna tadašnjem poimanju da je ženina neplodnost zapravo neka vrsta božanske retribucije: „Jakov se razljuti na Rahelu te reče: Zar sam ja namjesto Boga, koji ti je uskratio plod utrobe?,, (Post 30,2) ${ }^{26}$ Moguće je da je Rahela svome mužu Jakovu zapravo posredno davala naznake i nudila mu da uzme priležnicu, svoju sluškinju Bilhu, što Jakov nije odmah razumio pa mu je to Rahela trebala dodatno pojasniti: „Evo moje sluškinje Bilhe: uđi k njoj (בא אליה)

23 „The comic and ridiculous characteristics are emphasized. That is certainly true of the darkskinned Esau (the Palestinians noticed the much darker color of the eastern and southern inhabitants of the desert), and besides, the child was so hairy that he seemed to have been given a fur coat by nature."

24 Hetiti su intrigantna etnička skupina, domicilno iz područja Anatolije (današnja turska pokrajina).

25 Istovremeno, u židovskoj povijesti do naših dana židovski se etnicitet računa po majci, a ne po ocu. 
pa neka rodi na mojim koljenima, da tako i ja steknem djecu po njoj" (30,3). ${ }^{27}$

Ovo je, kao i kod Sare i Abrahama, još jedan od najizvornijih i najprimitivnijih slučaja surogat-majčinstva. Naime, Sara također upućujući svog muža Abrahama da "priđe“ k svojoj sluškinji Hagari, zaključuje: „možda ću (tako) $i$ ja imati djece". Skoro pa istovjetno, Rahela Jakovu nudi slično rješenje u obliku surogat-majčinstva tako što bi Bilha, njezina sluškinja, začela s njim i „rodila na njezinim koljenima“ $(30,3 \mathrm{~b})$.

\section{Nabal i Abigajila: "Ljepotica i budala"}

Bračna priča o Nabalu i Abigajili i njihovoj bračnoj neslozi razlikuje se od svih prethodnih bračnih pripovijesti. Bračne priče, koje smo do sada razmatrali i raščlanjivali, uglavnom se usredotočuju na uzajamno prebacivanje krivnje između bračnih partnera (Adam i Eva), problem bračne neplodnosti (Sara i Abraham, Rahela i Jakov), ili probleme koje uzrokuju djeca u obiteljskom životu (Izak i Rebeka).

Kod Nabala i Abigajile suočavamo se s novim izazovom. Riječ je o bračnom paru za koji bismo možda lako pronašli pandane u našem vremenu. Ovdje se radi o iznimno dobrostojećem, ali bahatom mužu (Nabalu) i mudroj ženi (Abigajili). ${ }^{28}$ U našem svijetu Nabala bismo vjerojatno smjestili među mačo-muškarce i tajkune, dok bi se Abigajila našla među privlačnim i mudrim ženama. Abigajila je žena bogatog Karmelićanina Nabala. ${ }^{29} \mathrm{U}$ imenima ovih supružnika, neizostavna je igra riječi; etimološki i onomastički, ime Nabal (glup) (usp. Beck 1962) dok je Abigajila (radost moga oca) (usp. Dalglish 1962). Kao i u mnogih drugih situacija onomastike i toponimije, imena su dakako opisna pa ponekad ne odgovaraju realnim situacijama. Naime, u ovom slučaju nije sasvim vjerojatno da bi roditelji svome djetetu nadjenuli ime Nabal (Glupko ili Budalić), što bi odgovaralo imenu Nabal. Dok, istovremeno Nabalova žena u susretu s Davidom uopće ne dvoji oko imena svoga muža i njegove naravi: "Neka moj gospodar ne gleda na toga opakog čovjeka, na Nabala, jer on s pravom nosi svoje ime: zove se Luda i ludost je s njim" (1 Sam 25,25).

Nabal je u svojoj gluposti bahat i nasilan čovjek. Bahatost njegova karaktera neizostavno je povezana i s njegovim imetkom. $\mathrm{U}$ ovoj se pripovijesti radi o tome

27 Ova situacija još jednom upućuje na našu prethodnu pretpostavku kako se u Starom zavjetu, unatoč poligamijskoj praksi, ipak radilo u osnovi o monogamnom braku. Štoviše, na to smo već ukazali u više primjera iz biblijskih tekstova, u prikazanim biblijskim brakovima mater familias ili koristeći suvremeni vokabular, „alfa žena“, bila je itekako prisutna i u tom biblijskom vremenu. “... taj se čovjek zvao Nabal, a njegova žena Abigajila. Žena je bila mudra i vrlo lijepa, a čovjek surov i opak: bio je Kalebovac"(1 Sam 25,3).

Abigaila usp. Beck 1962; Nabal usp. Dalglish 1962. 
da David sa svojom pratnjom, gladni, prolaze pustinjom i, načuvši o Nabalu i njegovu izobilju, traže samo kakav zalogaj za izgladnjelu kolonu („Podaj svojim slugama i svome sinu Davidu što ti se nađe pri ruci“, 1 Sam 25,8). Nabal odbija pružiti ikakvu pomoć. David i dio njegove skupine (1 Sam 25,13) spremaju se suočiti s Nabalom. Napetu situaciju spašava Nabalova žena Abigajila koja, bez znanja svoga muža, spremi nešto hrane za Davida i njegovu skupinu (1 Sam 25,18). Očito je da bračni odnosi u braku Nabala i Abigajile nisu bili ljubavni, skladni niti romantični. Štoviše, zbog ovakvoga nesretnog braka, čini se da se u svim ovim scenama mogu uočiti naznake romantične veze između Davida i Abigajile (usp. 1 Sam 25,23-31). Priča ima svoj zaključak kada bahati Nabal, nakon pijanke, doživi srčani udar i umire. Ovaj se toliko napio i obnevidio - „Nabal bijaše veseo i sasvim pijan" (1 Sam 25,36) da mu je Abigajila, njegova žena izjutra pojasnila što se sve zbivalo tijekom noći. Naime, David se već na toj gozbi spremao oduzeti život Nabalu i uništiti mu sve njegovo imanje, na što ga je odgovorila Abigajila: „tako mi živog Jahve, Boga Izraelova, koji nije dopustio da ti učinim zlo: da mi nisi tako brzo izišla u susret, zaista ne bi Nabalu do jutra ostalo ni ono što uza zid mokri!“ (1 Sam 25,34).

Pošto se Nabal izjutra otrijeznio i čuo od svoje žene što se dogodilo protekle noći, srce ga je izdalo: „njemu obamrije srce u grudima, i on osta kao da se skamenio" $(25,37)$. Nabal je nakon ovoga srčanog udara poživio još jedno kratko vrijeme „te umrije, (1 Sam 25,38). Odmah nakon njegove smrti, David zaprosi Abigajilu da mu bude ženom (1 Sam 25,39). Čini se da je romansa Davida i Abigajile počela još za života njezina muža Nabala, koji je pak svoj brak i bračnu zajednicu sustavno potkopavao bahatim mačo-pristupom.

\section{Zaključak}

Analizirajući neke probrane biblijske starozavjetne tekstove, dolazimo do sljedećih zaključaka. Unatoč prevladavajućem poimanju da su starozavjetni brakovi uglavnom poligamijski, pokazuje se da je brak i bračna zajednica Starog zavjeta ne samo naumljena biti monogamna, nego se i praktično takvom očituje. Čak i kada je naizgled ustrojena poligamno, u velikoj većini poligamno ustrojenih brakova, mater familias, ili alfa-žena, zapravo upravlja brakom i obitelji. Na to smo konkretno i tekstualno ukazali u primjerima bračnih zajednica koje smo analizirali.

U analizi bračnih razmirica utvrdili smo sljedeće obrasce koji su dovodili do bračnih konfliktnih situacija. Među ostalim, to su: uzajamno prebacivanje krivnje (Adam i Eva), ljubomora (Sara i Abraham), problem djece (Izak i Rebeka), neplodnost (Rahela i Jakov) i muška bahatost (Nabal i Abigajila). 


\section{Literatura}

Alter, Robert. 1985. The Art of Biblical Poetry. Edinburgh. T\&T Clark.

Beck, Harrell. 1962. „Abigail“. U Interpreter's Dictionary of the Bible, vol. 1. Nashville. Abingdon Press.

Berković, Danijel. 2016. Grammar of Death in the Psalms with Reference to Motion as Conceptual Metaphor (disertacija). Oxford-London.

Brnčić, Jadranka. 2014. Foucault o pareziji i parezija u kršćanstvu. Holon 4/2. str. 181-219.

Cohe, Irun. 2017. Kiša i uskrsnuće. Zagreb. Kruzak.

Dalglish, Edward. 1962. „Nabal“. U Interpreter's Dictionary of the Bible, vol. 3. Nashville. Abingdon Press.

Davidson, Richard. 2007. Flame of Yahweh: sexuality in the Old Testament. Massachusetts. Hendrickson.

Gelb, Ignace. 1962. „Hittites“. U Interpreter's Dictionary of the Bible, vol. 2. Nashville. Abingdon Press.

Greenberg, David. 1988. The Constructron of Homosexuality. Chicago. University of Chicago.

Jouon, Paul. 1993. A Grammar of Biblical Hebrew. Roma. PIB

Keil, C.F. \& Delitzsch, F. (KD). 1983. Commentary on the Old Testament in Ten Volumes. Grand Rapids. Eerdmans.

Prager, Dennis. 1993. Judaism's Sexual Revolution. Crisis 11/8.

Rad, Gerhard von. 1961. Genesis. London. SCM.

Rebić, Adalbert. 2004. Etiologija kao biblijski način tumačenja početaka. RijekaZagreb. Teologija u Rijeci. Biblijski institut KBF.

Vaux, Roland de. 1961. Ancient Israel: its Life and Institutions. London. DLT.

Višaticki, Karlo. 2004. Vjera kao vjernost Zakonu prema knjigama Ezra, Nehemija i Ljetopisi. U Stari zavjet, vrelo vjere i kulture. Rijeka-Zagreb. Teologija u Rijeci/KBF.

Wenham, Gordon. 1987. Genesis 1-15. Waco. Word Books. 


\title{
Danijel Berković
}

\section{Marriage and Marital Disputes in the Old Testament}

\begin{abstract}
In the introduction, the author emphasizes the significance and the importance of the narrative nature of the Old Testament text. This is with the purpose of emphasizing the directness and openness of the Old Testament narrative, where realistic life issues are openly and unapologetically discussed in the form of a story. Consequently, this raises the issues of understanding marriage and the marital union in the text and context of the Old Testament. The vocabulary and the language are analyzed. In the second part of the paper, the author focuses on the problems pertaining to marital and family communities; to marital disputes as we see them in the OT, using several Biblical marriages and the challenges they faced as examples.
\end{abstract}

